\title{
Consequences of immobilization and disuse: a short review
}

\author{
Francisco Fleury Uchoa Santos-Júnior, Dayanne Terra Tenório Nonato, \\ Francisco Sales Ávila Cavalcante, Paula Matias Soares, Vânia Marilande Ceccatto* \\ Laboratório de Bioquímica e Expressão Gênica (Labiex) - Instituto Superior de Ciências Biomédicas - Mestrado Acadêmico em \\ Ciências Fisiológicas (ISCB/CMACF)- Universidade Estadual do Ceará - UECE - Fortaleza/CE/Brasil \\ *Corresponding author E-mail: vania.ceccatto@uece.br
}

\begin{abstract}
Immobilization and disuse of a body part is quite common in the rehabilitation of patients suffering from injuries or diseases. There are a number of deleterious effects, including systems and organs such as the respiratory, cardiac and skeletal muscle. The clinical and physiological principal aspects revised in this short review are: muscular atrophy, general metabolic alterations, increase of connective tissue, muscular power loss, oxidative stress, loss of weight and neural changes. We conclude that immobilization/disuse should be evaluated and questioned if we really have indicated before being prescribed, as this causes many physiological and clinical deleterious effects.
\end{abstract}

Keywords: Immobilization, Disuse, Muscle atrophy, Rats.

\section{Introduction}

Patients suffering from temporary physical limitations are constant in the work of health professionals. Whether by accident or pathological conditions, these patients experience the difficult situation of having a part of the body immobilized, sometimes with a plaster splint, other by internal or external fixations. Both situations lead to the patients a provisional condition of limited full abilities restraining their locomotion movements, as well as their routine activities.

Immobilization is often used in clinical practice and is common in painful diseases and fractures. Few experimental studies have sought to contribute to its complete understanding. It is known, however that even short periods of immobilization causes damage to several immobilized regions, especially muscular atrophy [1]. Another important issue is that the immobilization causes disorders in other parts of the body, altering metabolism. Concerned this aspect, there is still a small number of studies [2,3].

Skeletal muscle atrophy is a highly ordered and regulated process with various metabolic, biochemical and structural changes which affect the functionality of the muscles involved. The structure and function of skeletal muscles are conditioned by proprioceptive activity, the motor innervation, mechanical load imposed by the tissue, by performing cycles of stretch / shortening and the mobility of joints. If any of these factors fail, it will develop a muscular atrophy [4].

Muscle tissue is characterized by performing contractions (cycles of stretch / shortening) and this contractile activity seems to have an important role in determining muscle mass and may precede the endocrine signals for the muscle proteins depletion. In addition, muscles kept inactive demonstrate to be sensitive to signals of catabolic counter regulatory hormones $[14,38]$. Studies with isolated muscles showed that the rate of amino acid transport activity is directly linked to contractile activity $[5,7]$.

The loss of muscle mass associated with loss of strength is one of the first and most obvious changes that occur as a result of immobilization, it's more pronounced in the first seventy-two hours, with rates decreasing from 14 to $17 \%$. Having lasted about a week, the pace of muscle loss seems to come down [8]. The rate of protein synthesis begins to decline six hours after the onset of disuse [9]. It was also observed that a higher course of time of immobilization causes further damage in the patient health, consecutively three weeks of immobilization may result in a $47 \%$ loss of muscular strength [10]. Skeletal muscles atrophy resulting from lack of load is one of the biggest changes associated with deconditioning, including interfering in routine activities [11]. 


\section{Materials and methods}

This study sought to review the literature through the scientific bases PubMed, Science Direct and Bireme focusing on 41 papers in last 33 years and providing an overview about immobilization in their physiological and clinical aspects using the keywords: bed rest, immobilization, physical immobility and disuse.

\section{Results and discussion}

Were selected 41 articles of which five were related by loss of weight, fourteen were related by muscular atrophy, six were related increase of connective tissue, ten were related by general metabolic alterations, two were related by oxidative stress, four were related by age Influence, five were related by neural change, seven were related by muscular power loss.

\section{Physiological aspects of immobilization}

Many immobilization studies point to muscular atrophy and metabolic alterations linked with this process (Table 1). Muscle atrophy appears to be a highly ordered and regulated process, characterized by decreased muscular fiber size [8, 12], cross-sectional area and protein content $[9,12]$, reduced muscle power, increased fatigability and increased insulin resistance. Compound action potential and the ultrastructure of the rat sciatic nerve are so also changed parameters after fourteen days of immobilization in adult male Wistar rats [13]. It is known that the decreased synthesis and increased protein degradation involved in this process contribute to the total loss of muscle protein due to disuse. This imbalance can be mainly attributed to oxidative stress [14].

Some factors influencing the reduction of contractile materials such as: $1^{\circ}$ the predominant fiber type in the muscle fibers to slow-oxidative type often present themselves most affected [15], $2^{\circ}$ the role that muscle plays the gravitational muscles are most affected [16], and $3^{\circ}$ the joint angle of immobilization, muscles immobilized in the shortened position seem to be more susceptible to atrophy [17]. Although there are different triggers associated to atrophy, the loss of muscle mass, in each case involves a common program that stimulates muscle proteolysis. Based on current knowledge of muscle atrophy related to an immobilization period, it is considered that this process involves an intrinsic interaction between two or more signaling pathways, rather than the perception of with a single responsible route [12].

According to Scott K. Powers [18], 2012 the first consideration of the oxidants in muscle atrophy appeared two decades ago, those findings led the authors to conclude that oxidative stress contributes to muscle atrophy. The disuse promotes an imbalance between oxidants and antioxidants, which results in accumulation of the first. The indirect indices of increased reactive oxygen species (ROS), occurs due to a large redox imbalance, causing oxidative damage. The mitochondria are the key part in the research because it is the place in inactive muscle fiber, where the production of ROS occurs. In theory, inactivity-induced reactive oxygen species production in skeletal muscle fibers can power amplify proteolysis by increasing the expression of components of the ubiquitin-proteasome system (eg, atrogin-1) and autophagy, allosteric activation of proteases, and oxidizing proteins, which increases their susceptibility to proteolytic degradation and recognition.

These correlations are based on the reduction in muscle size and the possible decrease in tension per unit of the muscle cross-sectional area [27]. In animals subjected to immobilization using plaster bandage method in order to analyze the respiratory muscles, there was muscle atrophy of the diaphragm associated with weight reduction of the muscle itself. This fact confirms that models of immobilization involving the animal trunk may limit the inspiration amplitude leading to a situation of sub-utilization and consequent atrophy of respiratory muscles [19]. The same results were found in relation to the heart muscle, myocardial hypotrophy, as well as a general reduction of the animal body mass, both utilizing the same immobilization protocols and maintained for two weeks [20].

Development or atrophy of skeletal muscle depends on the balance between synthesis rate and the rate of intracellular protein degradation [21]. The insulin actions of the proteins metabolism and amino acids are oriented toward to anabolic processes [22]. Insulin, after interacting with the membrane receptor, stimulates the translocation of glucose transporters, mainly the protein transporters GLUT-4, facilitating the entry of glucose into the cell, and exerting an anabolic effect on protein metabolism through the following mechanisms: stimulating amino acid transport into the cell, increasing the level ribosomal efficiency of the translation process, acting in the initiation step of the protein synthesis [23].

In several physiological conditions, glucose transport across the cell membrane is a limiting step in glucose utilization by skeletal muscle [24, 25]. Insulin and exercise are the most physiologically relevant stimulators of glucose transport in this tissue [26, 27]. Sedentary lifestyle is a factor that contributes to the development or increased resistance to insulin [28]. Therefore, immobilization generates a situation that goes against the protein synthesis by modifying the 
levels of glucose within the muscle, through a change in insulin resistance, which creates a pattern of difficult access to this hormone.

These insulin actions on protein metabolism are particularly important in muscle but are also present in greater or lesser extent in other tissues. In addition to its action at ribosomal level, insulin shares with the Insulin-like Growth Factors (IGFs) the ability to stimulate cell growth and, therefore, protein synthesis, acting in the transcription and increasing mRNA synthesis. The anabolic effects of this hormone are enhanced by their anti-catabolic actions. Insulin inhibits proteolysis, suppresses the release and inhibits the oxidation of essential amino acids [29].

All this negative disuse aspects can be evidenced and reconsidered by health professionals to in a second moment don't create troubles for patients in their physical rehabilitation.

\section{Clinical aspects of immobilization}

Among the medical complications arising from disuse and immobilization in cardiovascular system, there are: increased heart rate (HR), decreased cardiac reserve, orthostatic hypotension, and venous thrombo embolism.

A direct relationship with cardiac tissues is the increase in HR (usually more than 80 beats / min) due to immobilization, probably caused by an increased activity of the sympathetic nervous system. During rest, the basal HR increases one beat per minute every two days. As result of this increase, it has a shorter duration of diastole and thus end up affecting systole. Consequently, the heart is less able to respond to metabolic demands above the baseline level. Therefore, a shorter diastole reduces coronary blood flow and reduces oxygen available for cardiac muscle [30]. This might be related to a reduction in fiber diameter and weight of the myocardium shown in a previous study [20].

When we talk about muscle some things are classical in disuse, which involve the muscle activity. In a work with member suspension performed by Guillot et al. [31], the suspension generated a change in neuronal recruitment of the immobilized muscles, favoring flexors over extensors; collaborating with this hypothesis a study by Baroni et al., [32] which evaluated the production of force by muscle activation (EMG) and concluded that the EMG activity was reduced by immobilization in patients after ankle sprain in the anterior tibialis and soleus muscles, the reduction in muscle electrical activity may have occurred due to a neural adaptation supported in reflex inhibition of the muscle that occurs after trauma, surgical procedures and immobilization period. In disuse, the movement restriction occurs in muscle that decreases the number of functional motor units in activity, which persists even after removal of immobilization [33].

The skeletal muscle tissue is composed primarily of contractile components and there is also a close association between these elements and the muscle connective tissue (CT). Thus, the elastic behavior of skeletal muscle is determined not only by the contractile components, but also by this second tissue [34]. In skeletal muscle, 1-10\% of its mass is formed by connective tissue, and this percentage varies between muscles with different functions [35, 6]. Britt Christensen et al [36] evaluated the collagen turnover in the Achilles tendon after a period of immobilization and remobilization of triceps surae in patients with fracture of the ankle. They measured the peritendinous concentrations of $\mathrm{NH}_{2}$-terminal propeptide of type I collagen (PINP) and COOH-terminal telopeptide region of type I collagen (ICTP), markers are indexes of type I collagen synthesis and degradation, respectively. Both markers were increased in immobilized leg compared with control leg after the $7 \mathrm{wk}$ of immobilization, and levels decreased again in the immobilized leg during the recovery period. Immobilization increased both collagen synthesis and degradation in tendon near tissue, inducing a remodeling of fibers.

In the same idea, Kannus et al, [37] observed a significant increase in intramuscular connective tissue area (soleus: $18.9 \%$ in immobilized left hindlimb vs. $3.6 \%$ in nonimmobilized right hindlimb), relative number of muscle fibers with pathological alterations (soleus: $66 \%$ in immobilized hindlimb vs. $6 \%$ in control), decrease in the intramuscular capillary density (soleus: mean capillary density in the immobilized hindlimb only $63 \%$ of that in the nonimmobilized hindlimb). This increase in CT produces a mechanical barrier complicating the blood supply of muscle fibers that surround it reducing the capillary per fiber rate. This proliferation of CT increases the contact of the collagen fibers to each other stimulating the formation of abnormal cross-linking and obtaining, as a result of this process, the loss of extensibility and increased tissue stiffness [38].

Suetta [39] conducted a study in which they compared the effects of age on changes in contractile properties of skeletal muscles, strength and muscle mass in individuals subjected to immobilization and remobilization noted that the decline in quadriceps volume and pennation angle was smaller in old compared with young. After retraining, both young and old regained their initial muscle strength, but old had smaller gains in quadriceps volume compared with young, and pennation angle increased in young only. It's demonstrate that aging alters the neuromuscular response to short term disuse and recovery in humans. Notably, immobilization had a greater impact on neuronal motor function in old individuals, while young individuals were more affected at the muscle level. In addition, old individuals showed an attenuated response to retraining after immobilization compared with young individuals.

Already a survey conducted by Couppé [40], compared the effects of the mechanical properties of the patellar tendon in young and older adults who were evaluated before and after 14 days of immobilization there was no statistical 
difference between groups, concluded that short-term immobilization led to impaired mechanical properties of the patellar tendon on the immobilized side in both young men and old men, which can influence the function of the muscle-tendon complex.

One of the possible causes that explain the young individuals presenting a reduction of protein lost during immobilization is the IGF growth factor (insulin-like). The GH growth hormone released by the pituitary gland, when it reaches the liver is a substance similar to the insula and when combined formed the IGF, this factor comes in when there are specific receptors in the muscle membrane of the nucleus that absorbs this information to increase generating factor metabolism, thereby increasing the protein synthesis, the IGH is also one of the factors capable of activating satellite cells responsible for regeneration of muscle fibers. However, this process only occurs during youth, or during the release of GH growth hormone to approximately 30 years of age. After ceased GH protein synthesis occurs mainly by MGH (mechanical growth factor) is independent of $\mathrm{GH}$, or even older people produce, is stimulated by increased tensile strength, or elongation or contraction of the muscle, increasing production and subsequently picked up by muscular fiber core which, in turn, increase metabolism and protein synthesis [41].

\begin{tabular}{|c|c|c|}
\hline Subject & $\begin{array}{l}\text { Number of } \\
\text { articles }\end{array}$ & References \\
\hline Loss of weight & 5 & $\begin{array}{c}\text { Booth, 1992; Machida and Booth, 2004; Falempin and Mounier, 1998; Santos-Junior et al., 2010a; } \\
\text { Santos-Junior et al., 2010b }\end{array}$ \\
\hline $\begin{array}{l}\text { Muscular } \\
\text { atrophy }\end{array}$ & 14 & $\begin{array}{l}\text { Caierão et al., 2007; Ferreira et al., 2004; Booth, 1992; Machida and Booth, 2004; Falempin and Mounier, 1998; } \\
\text { Norman } \text { et al., 2000; Zhang et al., 2007; Guillot et al. (2008), Santos-Junior et al., 2010a; Kimball et al., 1994; } \\
\text { Santos-Junior et al., 2010b, Clarck BD, 2009, Gondin J, 2004, Fujita N, } 2009\end{array}$ \\
\hline $\begin{array}{l}\text { Increase of } \\
\text { connective tissue }\end{array}$ & 6 & $\begin{array}{c}\text { Józsa et al., 1988; Purslow, 2002; Mcdonough, 1981, Britt Christensen et al., } 2008 \text { Kannus et al, 1998, } \\
\text { Couppé C, } 2012 .\end{array}$ \\
\hline $\begin{array}{l}\text { General } \\
\text { metabolic } \\
\text { alterations }\end{array}$ & 10 & $\begin{array}{l}\text { Appell, 1990; Williams and Goldspink, 1984; Goldberg, 1979; Wasserman and Vranic, 1986.Santos-Junior et al., } \\
\text { 2010b; Carson, 1997; Zhang et al., 2007; Kimball et al., 1994; O'brien and Granner, 1991; Tsai et al., } 2006\end{array}$ \\
\hline Oxidative Stress & 2 & Pelegrino, 2011, Scott K. Powers, 2012 \\
\hline Age Influence & 4 & C. Suetta 2009, C. Couppé, 2012, Stevens-Lapsley, 2010, Hvid L, A. P, 2010 \\
\hline Neural Changes & 5 & Guillot et al. (2008), Baroni et al., 2010, Lars Hvid et al., 2010, Gondin J, 2004, Alves et al., 2013 \\
\hline $\begin{array}{l}\text { Muscular power } \\
\text { loss }\end{array}$ & 7 & $\begin{array}{l}\text { Booth, 1992; Machida and Booth, 2004; Falempin and Mounier, 1998; Hortobágyi et al., 2000; } \\
\text { Zhang et al., 2007, Baroni et al., 2010, Lars Hvid et al., } 2010\end{array}$ \\
\hline
\end{tabular}

\section{Conclusion}

Despite being a very useful resource for treating skeletal muscle injuries, several deleterious effects occur in the body after a period of immobilization or disuse. We conclude that immobilization/disuse should be evaluated and questioned if we really have indicated before being prescribed, as this causes many physiological and clinical deleterious effects that can make difficult the patient rehabilitation.

\section{Acknowledgements}

This work was supported by Funcap, CNPq and CAPES by research resources and grants.

\section{References}

[1] Caierão, Q. M., Teodori, R. M. \& Minamoto, V. B. (2007).The influence of immobilization on the muscle connective tissue: a review. Fisioterapia em Movimento, 20(3), 87-92. Available online: http://www2.pucpr.br/reol/index.php/RFM?dd1=1599\&dd99=pdf

[2] Appell, H. J. (1990). Muscular atrophy following immobilization: a review. Journal of Sports Medicine, 10(1), 42-58. Available online: http://www.ncbi.nlm.nih.gov/pubmed/2197699

[3] Williams, P.E. \& Goldspink G. (1984). Connective tissue changes in immobilized muscle. Journal of Anatomy, 138(2), 343-50. Available online: http://www.ncbi.nlm.nih.gov/pmc/articles/PMC1164074/?page=1

[4] Ferreira, R., Neuparth, M. J., Ascensão, A., Magalhães, J., Duarte, J. \& Amado, F. (2004). Skeletal muscle atrophy. Experimental models, tissue manifestations and pathophysiology. Revista Portuguesa de Ciências do Desporto, 4(3), 94-111. 
[5] Goldberg, A. (1979). Influence of insulin and contractile activity on muscle size and protein balance. Diabetes, 28(1),18-24. Available online: http://europepmc.org/abstract/MED/761710

[6] Wasserman, D. H. \& Vranic, M. (1986). Interaction between insulin and counter regulatory hormones in controlo f substrate utilization in health and diabetes during exercise. Diabetes: Metabolism Reviews, 1(4), 359-384. Available online: http://onlinelibrary.wiley.com/doi/10.1002/dmr.5610010403/abstract

[7] Carson, J. A. (1997). The regulation of gene expression in hypertrophing skeletal muscle. Exercise and Sport Sciences Reviews. 25, 301-20.

[8] Machida, S. \& Booth, F. W. (2004). Regrowth of skeletal muscle atrophied from inactivity. Medicine and Science in Sports Exercise, 36(1), 52-59. Available online: http://europepmc.org/abstract/MED/14707768

[9] Falempin, M. \& Mounier, Y. (1998). Muscle atrophy associated with microgravity in rat: basic data for countermeasures. Acta Astronautica, 42, 489-502. Available online: http://dx.doi.org/10.1016/S0094-5765(98)00141-6

[10] Hortobágyi, T., Dempsey, L., Fraser, D., Zheng, D., Hamilton, G., Lambert, J. \& Dohm, L. (2000). Changes in muscle strength, muscle fiber size and myofibrillar gene expression after immobilization and retraining in humans. Journal of Physiology, 524(1), 293-304. Available online: http://jp.physoc.org/content/524/1/293

[11] Norman, T. L., Bradley-Popovich, G. \& Clovis, N. (2000). Aerobic exercise as a countermeasure for microgravity - induced bone loss and muscle atrophy in a rat hindlimb suspension model. Aviation, Space, and Environmental Medicine, 71(6), 593-8. Available online: http://www.ncbi.nlm.nih.gov/pubmed/10870818

[12] Zhang, P., Chen, X. \& Fan, M. (2007). Signaling mechanisms involved in disuse muscle atrophy. Medical Hypotheses, 69(2), 310-321. Available online: http://dx.doi.org/10.1016/j.mehy.2006.11.043

[13] Alves, J. S., Leal-Cardoso, J. H., Santos-Júnior, F. F., Carlos P. S., Silva, R. C., Lucci, C. M., Báo, S. N., Ceccatto, V. M., Barbosa, R. (2013). Limb immobilization alters functional electrophysiological parameters of sciatic nerve. Brazilian Journal of Medical and Biological Research, 16; [Epub ahead of print]. Available online: http://www.ncbi.nlm.nih.gov/pubmed/23969978

[14] Pellegrino, M. A., Desaphy, J-F., Brocca, L., Pierno, S., Camerino, D. C., Bottinelli, R. (2011). Redox homeostasis, oxidative stress and disuse muscle atrophy, Journal of Physiology, 589, 2147-2160. Available online: http://jp.physoc.org/content/589/9/2147.long

[15] Gondin, J., Guette, M., Maffiuletti, N. A. \& Martin, A. (2004). Neural activation of triceps surae is impaired following 2 weeks of immobilization. European Journal of Applied Physiology, 93(3), 359-65. Available online: http://link.springer.com/article/10.1007\%2Fs00421-004-1225-z

[16] Clark, B. C. (2009). In vivo alterations in skeletal muscle form and function after disuse atrophy. Medicine Science in Sports Exercise, 41(10), 1869-1875.Available online: http://journals.lww.com/acsm$\mathrm{msse} /$ pages/articleviewer.aspx year $=2009 \&$ issue $=10000 \&$ article $=00006 \&$ type $=$ abstract

[17] Fujita, N., Fujimoto, T., Tasaki, H., Arakawa, T., Matsubara, T. \& Miki, A. (2009). Influence of muscle length on muscle atrophy in the mouse tibialis anterior and soleus muscles. Biomedical Research, 30(1), 39-45.Available online: https://www.jstage.jst.go.jp/article/biomedres/30/1/30_1_39/_article

[18] Powers, S. K., Smuder, A. J. \& Judge, A. R. (2012). Oxidative stress and disuse muscle atrophy: cause or consequence? Current Opinion in Clinical Nutrition and Metabolic Care, 15(3), 240-245.Available online: http://journals.lww.com/coclinicalnutrition/pages/articleviewer.aspx?year $=2012 \&$ issue $=05000 \&$ article $=00008 \&$ type $=$ abstract

[19] Santos-Junior, F. F. U., Alves, J. S. M., Machado, A. C. N., Carlos, P. S., Ferraz, A. S. M., Barbosa, R., Cardoso, J. H. \& Ceccatto, V. M. (2010). Morphometric changes in respiratory muscle of rats subjected to immobilization. Revista Brasileira de Medicina do Esporte, 16(3), 215-218. Available online: http://dx.doi.org/10.1590/S1517-86922010000300012

[20] Santos-Júnior, F. F. U., Alves, J. S. M., Carlos, P. S., Forte, F. E. S., Barbosa, R. \& Ceccatto, V. M. (2010). Morphometric changes in the myocardium after immobilization. Terapia Manual 8(40), 21-24.

[21] Kimball, S. R., Vary, T. C. \& Jefferson, L. S. (1994). Regulation of protein synthesis by insulin. Annual Review of Physiology, $56,321-48$. Available online: http://www.ncbi.nlm.nih.gov/pubmed/16545079

[22] O'brien, R. M., Granner, D. K. (1991). Regulation of gene expression by insulin. Biochemical Journal, 278(3), 609-19. Available online: http://www.ncbi.nlm.nih.gov/pmc/articles/PMC1151391/?page=1

[23] Tsai, Y. L., Hou, C. W., Liao, Y. H., Chen, C. Y., Lin, F. C., Lee, W. C., Chou, S. W. \& Kuo, C. H. (2006). Exercise training exacerbates tourniquet ischemia-induced decreases in GLUT 4 expression and muscle atrophy in rats. Life Sciences, 78(25), 2953-2959. Available online: http://dx.doi.org/10.1016/j.lfs.2005.11.021

[24] Kubo, K., Foley, J. E. (1986). Rate-limiting steps for insulin mediated glucose uptake into perfused rat hindlimb. American Journal of Physiology, 250(1), 100-102. Available online: http://ajpendo.physiology.org/content/250/1/E100.reprint

[25] Cline, G. W., Petersen, K. F., Krssak, M., Shen, J., Hundal, R. S., Trajanoski, Z., Inzucchi, S., Dresner, A., Rothman, D. L. \& Shulman, G. I. (1999). Impaired glucose transport as a cause of decreased insulin stimulated muscle glycogen synthesis in type 2 diabetes. New England Journal of Medicine, 341(4), 240-246. Available online: http://www.nejm.org/doi/full/10.1056/NEJM199907223410404

[26] Hayashi, T., Wojtaszewski, J. F. \& Goodyear, L. J. (1997). Exercise regulation of glucose transport in skeletal muscle. American Journal of Physiology 273, 1039-1051. Available online: http://ajpendo.physiology.org/content/273/6/E1039.full.pdf+html

[27] Goodyear, L. J. \& Kahn, B. B. (1998). Exercise, glucose transport, and insulin sensitivity. Annual Review of Medicine, 49, 235-261. Available online: http://www.uoguelph.ca/hhns/undergrad/courses/NUTR4350/NUTR4350F04Goodyear.pdf

[28] Bassuk, S. S. \& Manson, J. E. (2005). Epidemiological evidence for the role of physical activity in reducing risk of type 2 diabetes and cardiovascular disease. Journal of Applied Physiology, 99(3), 1193-1204. Available online: http://jap.physiology.org/content/99/3/1193.long

[29] Luciano E, \& Mello M. A. R. (1998). Physical activity and protein metabolism in muscle of diabetic rats. Revista Paulista de Educação Física, 12(2), 202-09.Available online: http://citrus.uspnet.usp.br/eef/uploads/arquivo/v12\%20n2\%20artigo9.pdf

[30] Dittmier, D. K. \& Teasell, R. (1993). Complications of immobilization and bed rest. Part 1: Musculoskeletal and cardiovascular $\begin{array}{lcccc}\text { complications. } & \text { Canadian } & \text { Family } & \text { Physician, } & 3,1428-1437 .\end{array}$ http://www.ncbi.nlm.nih.gov/pmc/articles/PMC2379624/?page=1".

[31] Guillot, G., Steinberg, J. G., Delliaux, S., Kipson, N., Jammes, Y. \& Badier, M. (2008). Physiological, histological and biochemical properties of rat skeletal muscles in response to hindlimb suspension. Journal of Electromyography and Kinesiology, 18, 276-283. Available online: http://dx.doi.org/10.1016/j.jelekin.2006.10.001

[32] Baroni, B. M., Galvão, A. Q., Ritzel, C. H., Diefenthaeler, F. \& Vaz, M. A. (2010). Adaptações neuromusculares de flexores dorsais e plantares a duas semanas de imobilização após entorse de tornozelo. Revista Brasileira de Medicina do Esporte, 16(5), 358-362.Available online: http://www.scielo.br/pdf/rbme/v16n5/v16n5a08.pdf

[33] Hvid, L. A. P., Justesen, L., Bayer, M. L., Andersen, J. L., Ørtenblad, N., Kjaer, M. \& Suetta, C. (2010). Effects of aging on muscle mechanical function and muscle fiber morphology during short-term immobilization and subsequent retraining. Journal of Applied Physiology, 109(6), 1628-1634. Available online: http://jap.physiology.org/content/109/6/1628.long 
[34] Józsa L, Thöring J, Jarvinen M, Kannus P, Lehto M, Kvist M. Quantitative alterations in intramuscular connective tissue following immobilization: an experimental study in the rat calf muscles. Exp Mol Pathol (1988) 49(2), 267-278. Available online: http://dx.doi.org/10.1016/0014-4800(88)90039-1

[35] Purslow, P. P. (2002). The structure and functional significance of variations in the connective tissue within muscle. Comparative Biochemistry and Physiology, 133(4), 947-966. Available online: http://dx.doi.org/10.1016/S1095-6433(02)00141-1

[36] Christensen, B., Dyrberg, E., Aagaard, P., Kjaer, M. \& Langberg, H. (2008). Short-term immobilization and recovery affect skeletal muscle but not collagen tissue turnover in humans. Journal of Applied Physiology, 105, 1845-1851. Available online: http://jap.physiology.org/content/105/6/1845.long

[37] Kannus, P., Laszlo, J., Teppo, L. N., Jarvinen, M. K., Toini, V., Tero, A. H. Jarvinen, A. N. \& Markku, J. (1998). Free mobilization and low to high-intensity exercise in immobilization-induced muscle atrophy. Journal of Applied Physiology, 84(4), 1418-1424. Available online: http://jap.physiology.org/content/84/4/1418.full.pdf+html

[38] McDonough, A. L. (1981). Effects of immobilization and exercise on articular cartilage: a review of the literature. Journal of Orthopaedic and Sports Physical Therapy, 3(1), 2-5. Available online: http://www.ncbi.nlm.nih.gov/pubmed/18810142

[39] Suetta, C., Hvid, L. G., Justesen, L., Christensen, U., Neergaard, K., Simonsen, L., Ortenblad, N., Magnusson, S. P., Kjaer, M. \& Aagaard, P. (2009). Effects of aging on human skeletal muscle after immobilization and retraining. Journal of Applied Physiology, 107, 1172-1180. Available online: http://www.jappl.org/content/107/4/1172.short

[40] Couppé, C., Suetta, C., Kongsgaard, M., Justesen, L., Hvid, L. G., Aagaard, P., Kjær, M., \& Magnusson, S. P. (2012). The effects of immobilization on the mechanical properties of the patellar tendon in younger and older men. Clinical Biomechanics, 27(9), 949-954 Available online: http://www.clinbiomech.com/article/S0268-0033(12)00128-3/abstract

[41] Stevens-Lapsley, J. E., Fan, Y. E., Min, L., Stephen, E. B., Christine, C., Kevin, E. Y., Walter, G. A., Sweeney, H. L., Vandenborne, K. (2010). Impact of viral-mediated IGF-I gene transfer on skeletal muscle following cast immobilization. American Journal of Physiological Endocrinology and Metabolism, 299, E730-E740. Available online: http://ajpendo.physiology.org/content/299/5/E730.long". 